\title{
Health disparities between Muslim and non-Muslim countries
}

\author{
J.A Razzak, ${ }^{1}$ U.R. Khan, ${ }^{7}$ I. Azam, ${ }^{1}$ M. Nasrullah, ${ }^{2}$ O. Pasha, ${ }^{1}$ M. Malik ${ }^{1}$ and A. Ghaffar ${ }^{3}$
}

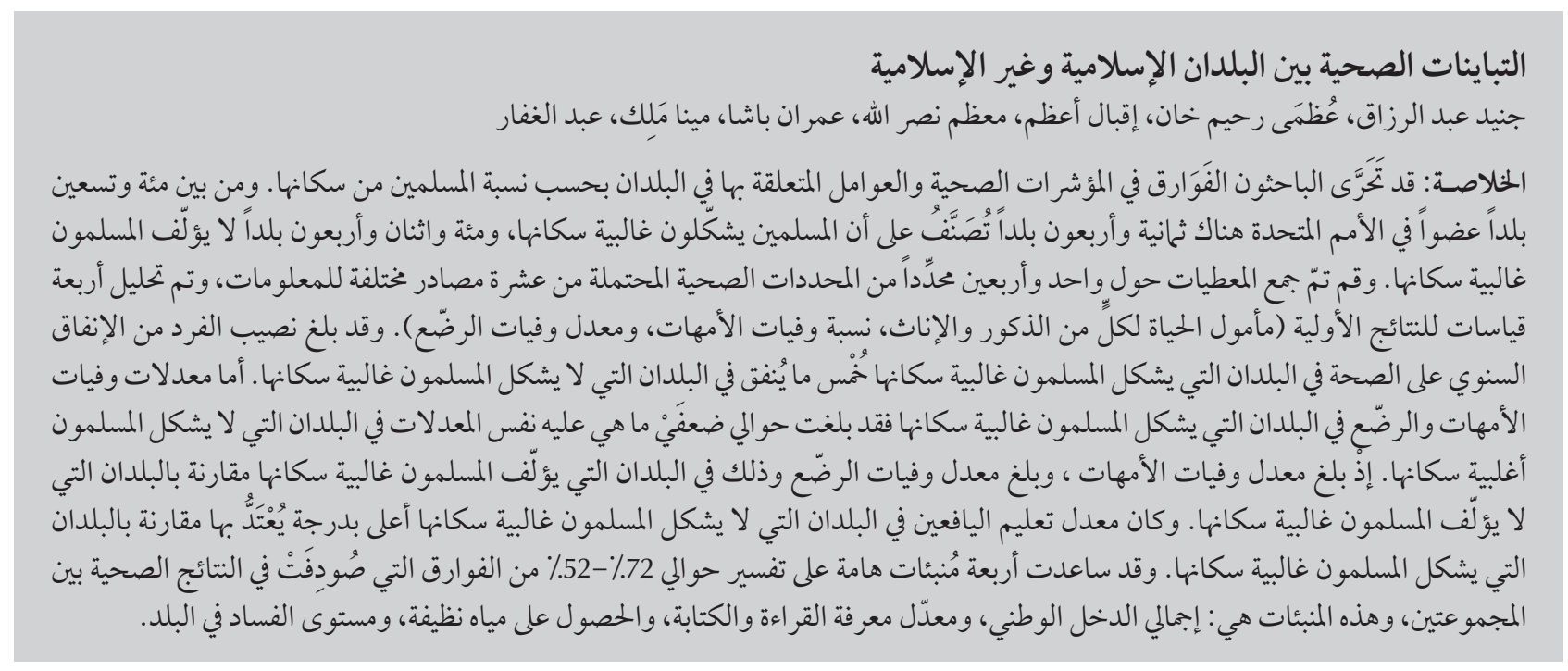

ABSTRACT We examined differences in health indicators and associated factors across countries according to the proportion of the population who are Muslim. Of 190 UN countries, 48 were classified as Muslim-majority countries (MMC) and 142 as non-MMC. Data on 41 potential determinants of health were obtained from 10 different data sources, and 4 primary outcome measures (male and female life expectancy, maternal mortality ratio and infant mortality rate) were analysed. Annual per capita expenditure on health in MMC was one-fifth that of nonMMC. Maternal mortality and infant mortality rates were twice as high in MMC as non-MMC. Adult literacy rate was significantly higher for non-MMC. Four significant predictors explained $52 \%-72 \%$ of the differences in health outcomes between the 2 groups: gross national income, literacy rate, access to clean water and level of corruption.

\section{Disparités en matière de santé entre pays musulmans et non musulmans}

RÉSUMÉ Nous avons examiné les différences entre les indicateurs de santé et les facteurs associés dans différents pays en fonction de la proportion de la population musulmane. Sur 190 pays membres des Nations Unies, 48 étaient classés comme des pays à majorité musulmane et 142 comme des pays à majorité non musulmane. Des données ont été obtenues sur 41 déterminants potentiels de la santé à partir de dix sources d'information différentes, et quatre mesures principales de résultats (l'espérance de vie pour les hommes et pour les femmes, le taux de mortalité maternelle et le taux de mortalité infantile) ont été analysées. Les dépenses de santé annuelles par habitant dans les pays majoritairement musulmans correspondaient au cinquième des dépenses dans les autres pays. Les taux de mortalité maternelle et infantile étaient deux fois plus élevés dans les pays à majorité musulmane. Le taux d'alphabétisation des adultes était nettement supérieur dans les pays à majorité non musulmane. Quatre facteurs prédictifs importants expliquaient 52 à $72 \%$ des différences dans les résultats sanitaires entre les deux groupes : le revenu national brut, le taux d'alphabétisation, l'accès à l'eau salubre et le niveau de corruption 


\section{Introduction}

Despite impressive gains in health and longevity during the 20th century substantial health disparities exist between countries $[1,2]$. Today, people living in the poorest countries of the world live 30 years less than those living in economically advanced countries [3]. Life expectancy for children born in Europe has increased by 30 years in the last century compared to 4 months for children born in sub-Saharan Africa [4].

Research on disparities in health has focused primarily on the relationship between health outcomes and population factors such as race, income level, sex, age groups and education levels [3]. Like gender and race, religion forms part of the context that generates social inequalities and could influence the position a person occupies in their society and thus impact their health outcomes [5]. Study of health outcomes according to the religious affiliation of populations has focused on minority populations in some countries or on specific diseases [6,7]. Muslims, the followers of the religion of Islam, form one of the largest religious groups in the world with an estimated population of 1.4-1.5 billion [8]. Comprising many ethnic groups spread across the globe and connected only by religious belief, Muslims are concentrated in 57 countries [8]. Concerns about the radicalization of Muslim populations have prompted a growing interest in the last decade in the social development of Muslim countries [9].

We undertook this study to examine differences in 4 key health indicators (male and female life expectancy, infant mortality rates and maternal mortality ratios) between countries with a predominantly Muslim population and non-Muslim majority countries and to identify factors possibly contributing to this difference based on national aggregate data.

\section{Methods}

\section{Study population}

For the purpose of this study, 190 countries were classified into 2 groups. Muslim majority countries (MMC) were defined as countries with a 50\% or greater Muslim population [10]. All other United Nations (UN) member states, irrespective of the number of Muslims, were designated as nonMMC. The 142 non-MMC and 48 MMC were subdivided into 4 groups based on the UN classification of gross national income (GNI) per capita in 2006 which is gross domestic product (GDP) less net taxes on production and imports, less compensation of employees and property income payable to the rest of the world plus the corresponding items receivable from the rest of the world. The 4 groups are: low income countries ( $\leq$ US\$ 905), lower middle income countries (US\$ 906-3595), upper middle income countries (US\$ 3596-11 115) and high income countries ( $\geq$ US\$ 11116 ) [11] (Tables 1 $\& 2)$.

\section{Data sources}

The 41 variables used in this study were compiled from 10 different data sources. The 2 major contributing data sources include the World Health Organization's Statistical Information System (WHOSIS) [12], and the Statistical Economic and Social Research and Training Center for Islamic Countries' (SESRIC) Basic and Social Economic Indicators Database (BASEIND) [13]. Other sources used to abstract data included Development Data Platform (DDP), Quick Query of the World Bank [14], the Human Development Reports of the United Nations Development Programme [15], online databases of the United Nations Statistics Division [16], United Nations International Children Education Fund (UNICEF) [1617 United Nations Population Fund [18] and United Nations Educational,
Scientific and Cultural Organization (UNESCO) [19], the World Fact Book [20] and Google Scholar [21]. The latest available data from year 2000 onwards were used in the analysis. No ethics clearance was required as data were gathered from publicly available data sources

\section{Measures}

\section{Outcomes}

Four primary outcome measures were used: male and female life expectancy (the number of years that a newborn can expect to live based on the current mortality rates), infant mortality rate (the probability of a child dying before the age of 1 year) and maternal mortality ratio (number of maternal deaths per 100000 live births) [22]. These have been used before in health situation analyses $[23,24]$.

\section{Independent variables}

Other independent variables were used for which data were available. A total of 37 independent variables were studied. These included indicators for demographic and socioeconomic status, population, education, health, governance, environmental factors, health service coverage and resources, external debt and military expenditure.

\section{Statistical methods}

All analyses were conducted using SPSS, version 16.0.

Independent samples $t$-test was used to estimate the mean differences of continuous variables such as literacy rate, life expectancy, maternal mortality ratio, infant mortality rate, under 5 years mortality, age standard mortality for noncommunicable diseases and per capita government expenditure by country status. The chi-squared test was used to compare the proportion of income status among MMC and non-MMC. Multicollinearity among 


\begin{tabular}{|c|c|c|c|}
\hline $\begin{array}{l}\text { Low-income non-Muslim } \\
\text { countries } \\
(n=32)\end{array}$ & $\begin{array}{l}\text { Lower-middle -income non- } \\
\text { Muslim countries } \\
\qquad(n=40)\end{array}$ & $\begin{array}{l}\text { Upper-middle -income non- } \\
\text { Muslim countries } \\
\qquad(n=32)\end{array}$ & $\begin{array}{l}\text { High-income non-Muslim } \\
\text { countries } \\
(\boldsymbol{n}=38)\end{array}$ \\
\hline Benin & Angola & Argentina & Andorra \\
\hline Burundi & Armenia & Belize & Antigua and Barbuda \\
\hline Cambodia & Belarus & Botswana & Australia \\
\hline Central African Republic & Bhutan & Brazil & Austria \\
\hline Congo & Bolivia & Bulgaria & Bahamas \\
\hline Cote d'Ivoire & Bosnia Herzegovina & Chile & Barbados \\
\hline Eritrea & Cameroon & Costa Rica & Belgium \\
\hline Ethiopia & Cape Verde & Croatia & Canada \\
\hline Ghana & China & Dominica & Cyprus \\
\hline Haiti & Colombia & Equatorial Guinea & Czech Republic \\
\hline India & $\begin{array}{l}\text { Congo (Demographic } \\
\text { Republic of) }\end{array}$ & Gabon & Denmark \\
\hline Kenya & Cuba & Granada & Estonia \\
\hline Korea Democratic Republic & Dominican Republic & Hungary & Finland \\
\hline $\begin{array}{l}\text { Lao (People's Democratic } \\
\text { Republic) }\end{array}$ & Ecuador & Latvia & France \\
\hline Liberia & El Salvador & Lithuania & Germany \\
\hline Madagascar & Fiji & Mauritius & Greece \\
\hline Malawi & Georgia & Mexico & Iceland \\
\hline Mongolia & Guatemala & Montenegro & Ireland \\
\hline Mozambique & Guyana & Palau & Israel \\
\hline Myanmar & Honduras & Panama & Italy \\
\hline Nepal & Jamaica & Poland & Japan \\
\hline Papua New Guinea & Kiribati & Romania & Korea (Republic of) \\
\hline Rwanda & Lesotho & Russian Federation & Luxembourg \\
\hline Sao Tome and Principe & $\begin{array}{l}\text { Macedonia (the former } \\
\text { Yugoslavia) }\end{array}$ & Serbia & Malta \\
\hline Solomon Islands & Marshall Islands & Seychelles & Monaco \\
\hline Tanzania (United Republic of) & $\begin{array}{l}\text { Micronesia (Federated } \\
\text { States of) }\end{array}$ & Slovakia & Netherlands \\
\hline Timor-Leste & Moldova (Republic of) & South Africa & New Zealand \\
\hline Togo & Namibia & St Kitts and Nevis & Norway \\
\hline Uganda & Nicaragua & St Lucia & Portugal \\
\hline Viet Nam & Paraguay & $\begin{array}{l}\text { St Vincent and the } \\
\text { Grenadines }\end{array}$ & San Marino \\
\hline Zambia & Peru & Uruguay & Singapore \\
\hline \multirow[t]{9}{*}{ Zimbabwe } & Philippines & Venezuela & Slovenia \\
\hline & Samoa & & Spain \\
\hline & Sri Lanka & & Sweden \\
\hline & Suriname & & Switzerland \\
\hline & Swaziland & & Trinidad and Tobago \\
\hline & Thailand & & United Kingdom \\
\hline & Tonga & & United States of America \\
\hline & Ukraine & & \\
\hline & Vanuatu & & \\
\hline
\end{tabular}




\begin{tabular}{|c|c|c|c|}
\hline $\begin{array}{l}\text { Low-income Muslim } \\
\text { countries } \\
(n=21)\end{array}$ & $\begin{array}{l}\text { Lower-middle income } \\
\text { Muslim countries } \\
\qquad(\boldsymbol{n}=15)\end{array}$ & $\begin{array}{l}\text { Upper-middle-income } \\
\text { Muslim countries } \\
\qquad(n=6)\end{array}$ & $\begin{array}{l}\text { High-income Muslim } \\
\text { countries } \\
(n=6)\end{array}$ \\
\hline Afghanistan & Albania & Kazakhstan & Bahrain \\
\hline Bangladesh & Algeria & Lebanon & Brunei Darussalam \\
\hline Burkina Faso & Azerbaijan & Libyan Arab Jamahiriya & Kuwait \\
\hline Chad & Djibouti & Malaysia & Qatar \\
\hline Comoros & Egypt & Oman & Saudi Arabia \\
\hline Gambia & Indonesia & Turkey & United Arab Emirates \\
\hline Guinea & Iran (Islamic Republic of) & & \\
\hline Guinea-Bissau & Iraq & & \\
\hline Kyrgyzstan & Jordan & & \\
\hline Mali & Maldives & & \\
\hline Mauritania & Morocco & & \\
\hline Niger & Palestine & & \\
\hline Nigeria & Syrian Arab Republic & & \\
\hline Pakistan & Tunisia & & \\
\hline Senegal & Turkmenistan & & \\
\hline \multicolumn{4}{|l|}{ Sierra Leone } \\
\hline \multicolumn{4}{|l|}{ Somalia } \\
\hline \multicolumn{4}{|l|}{ Sudan } \\
\hline \multicolumn{4}{|l|}{ Tajikistan } \\
\hline \multicolumn{4}{|l|}{ Uzbekistan } \\
\hline Yemen & & & \\
\hline
\end{tabular}

independent variables was assessed by Pearson, Cramer and eta statistics at the cut-off 0.8 , above which correlation is strong.

Simple linear regression was performed to determine the association of the independent variables with the 4 primary outcome variables. Association between all the variables used in univariate analysis was also performed by adjusting the primary exposure (country majority religion) with the outcomes.

Multiple linear regression analysis was performed to determine independent relationships between outcomes and potential predictors. Adjustment variables were selected by sequentially adding significant predictors from the univariate analysis into the model. Two separate sets of models were estimated for all 4 outcomes. Once the stepwise selection was completed, the final model was refitted using only the variables significant at the $5 \%$ of level.

\section{Results}

\section{Comparison of descriptive characteristics}

Table 3 summarizes the descriptive characteristics of the $190 \mathrm{MMC}$ and non-MMC according to the studied variables.

We found significant differences in health outcomes between MMC and non-MMC. The annual population growth rate for MMC was $1 \%$ more than in non-MMC on average (2.4\% versus $1.2 \%$; $95 \% \mathrm{CI}:-1.6 \%$ to -0.7$)$. Similarly, the mean values of maternal mortality ratio (455 versus 266 per 100000 births); $95 \% \mathrm{CI}$ : -350 to -7.5$)$, under 5 years mortality rate ( 80.5 versus 51.9 per 1000 live births; $95 \% \mathrm{CI}:-49.7$ to -7.5$)$ and infant mortality rate (56 versus 34 per 1000 live births; 95\% CI -34 to -10 ) were considerably worse in MMC. Years of potential life lost (YPLL) due to noncommunicable diseases were lower in MMC (38.1 versus 49.8 years; 95\% CI: 4.0 to 19.3), while YPLL due to communicable diseases were higher ( 47.8 versus 36.1 years; $95 \% \mathrm{CI}:-21.5$ to -2.0). A lower prevalence of HIV was found in MMC ( 839 versus 2653 per 100000 ; $95 \%$ CI: 691 to 2937) (Table 3).

Large differences were also found in the socioeconomic and education indicators. Almost half of non-MMC (49.3\%) were in the high- or uppermiddle-income group compared with one-quarter of MMC (25.0\%). The mean adult literacy rate was $85.0 \%$ for the non-MMC compared with $68.6 \%$ for the MMC (95\% CI: 7.6 to 24.0). Other differences were better access to safe water, a higher rate of contraceptive use and a higher gender equity index in non-MMC (Table 3).

There were fewer resources for health in MMC then in non-MMC. 


\begin{tabular}{|c|c|c|c|}
\hline Variable & $\begin{array}{l}\text { Muslim majority } \\
\qquad(n=48)\end{array}$ & $\begin{array}{l}\text { Non-Muslim majority } \\
\qquad(n=142)\end{array}$ & $\begin{array}{l}\text { 95\% } \mathrm{Cl} \text { for the } \\
\text { difference }\end{array}$ \\
\hline & Mean (SD) & Mean $(S D)$ & \\
\hline \multicolumn{4}{|l|}{ Demographic and socioeconomic indicators } \\
\hline Total life expectancy (years & $64.2(11.0)$ & $66.7(13.1)$ & -1.8 to 6.6 \\
\hline$<5$-year-old mortality rate (per 1000 live births) & $80.5(74.2)$ & $51.9(59.7)$ & -49.7 to -7.5 \\
\hline Total adult mortality rate (per 1000 population) & $237.9(125.5)$ & $217.7(144.4)$ & -67.1 to 26.6 \\
\hline \multirow[t]{2}{*}{ Total fertility rate (per woman) } & $3.8(1.7)$ & $2.7(1.4)$ & -1.5 to -0.4 \\
\hline & No. $(\%)$ & No. $(\%)$ & \\
\hline \multicolumn{4}{|l|}{ Income group } \\
\hline High & $6(12.5)$ & $38(26.8)$ & -28.3 to -0.3 \\
\hline Upper middle & $6(12.5)$ & $32(22.5)$ & -23.2 to 3.2 \\
\hline Lower middle & $15(1.2)$ & $40(28.2)$ & -11.8 to 17.8 \\
\hline \multirow[t]{2}{*}{ Low } & $21(3.8)$ & $32(22.5)$ & 6.9 to 35.7 \\
\hline & Mean (SD) & Mean (SD) & \\
\hline \multicolumn{4}{|l|}{ Population indicators } \\
\hline Population annual growth rate (\%) & $2.4(1.9)$ & $1.2(1.1)$ & -1.6 to -0.7 \\
\hline Urbanization (\%) & $53.1(23.0)$ & $55.8(23.1)$ & -5.0 to 10.3 \\
\hline \multicolumn{4}{|l|}{ Development and governance indicators } \\
\hline Gender equity index & $50.3(8.5)$ & $64.9(11.1)$ & 11.1 to 18.0 \\
\hline Human development index & $0.6(0.2)$ & $7.9(58.2)$ & -10.1 to 24.6 \\
\hline Democracy index & $3.8(1.5)$ & $6.3(2.1)$ & 2.0 to 3.1 \\
\hline Corruption perception index & $3.0(1.1)$ & $4.3(2.2)$ & 0.8 to 1.8 \\
\hline Military expenditure (\% of GDP) & $3.1(2.3)$ & $2.0(2.5)$ & -2.0 to -0.2 \\
\hline External debt (US\$) & $19.5(40.7)$ & $24.2(53.7)$ & -14.8 to 24.2 \\
\hline \multicolumn{4}{|l|}{ Education indicators } \\
\hline Total adult literacy rate (\%) & $68.6(25.8)$ & $85.0(16.8)$ & 7.6 to 24.0 \\
\hline Male adult literacy rate (\%) & $78.6(20.6)$ & $89.5(12.7)$ & 4.6 to 17.4 \\
\hline Female adult literacy rate (\%) & $65.2(28.3)$ & $84.5(19.6)$ & 10.4 to 28.2 \\
\hline $\begin{array}{l}\text { Public expenditure on education } \\
\text { (\% of GDP) }\end{array}$ & $4.1(2.4)$ & $4.9(1.9)$ & -0.1 to 1.7 \\
\hline $\begin{array}{l}\text { Public expenditure on education (\% of total } \\
\text { government exp.) }\end{array}$ & $17.5(7.0)$ & $14.9(5.1)$ & -5.3 to -0.1 \\
\hline \multicolumn{4}{|l|}{ Health indicators } \\
\hline Low birth weight (\% of births) & $13.4(7.4)$ & $9.8(4.7)$ & -6.0 to -11 \\
\hline HIV prevalence (per 100000 population) & 839 (1098) & $2653(5633)$ & 691 to 2937 \\
\hline YPLL communicable disease (years) & $47.8(26.0)$ & $36.1(30.1)$ & -21.5 to -2.0 \\
\hline YPLL noncommunicable disease (years) & $38.1(21.0)$ & $49.8(27.6)$ & 4.0 to 19.3 \\
\hline \multicolumn{4}{|l|}{ Environmental health factors } \\
\hline Improved water access (\% of population) & $77.5(19.5)$ & $85.7(16.6)$ & 2.1 to 14.1 \\
\hline Improved sanitation (\% of population) & $77.1(107.9)$ & $68.9(29.1)$ & -42.7 to 26.2 \\
\hline \multicolumn{4}{|l|}{ Health service coverage } \\
\hline Contraceptive use (\%) & $39.7(22.7)$ & $51.0(21.9)$ & 3.5 to 19.2 \\
\hline $\begin{array}{l}\text { Births attended by skilled health } \\
\text { personnel }(\%)\end{array}$ & $69.6(29.5)$ & $87.7(85.0)$ & -7.0 to 43.0 \\
\hline DPT immunization $(\%)^{\mathrm{b}}$ & $76.1(24.9)$ & $79.4(21.8)$ & -4.3 to 10.7 \\
\hline Measles immunization (\%) & $79.3(22.2)$ & $78.1(21.7)$ & -8.4 to 6.1 \\
\hline
\end{tabular}




\begin{tabular}{|c|c|c|c|}
\hline Variable & $\begin{array}{l}\text { Muslim majority } \\
\qquad(n=48)\end{array}$ & $\begin{array}{l}\text { Non-Muslim majority } \\
\qquad(n=142)\end{array}$ & $\begin{array}{l}\text { 95\% } \mathrm{Cl} \text { for the } \\
\text { difference }\end{array}$ \\
\hline & Mean (SD) & Mean (SD) & \\
\hline \multicolumn{4}{|l|}{ Health service resources } \\
\hline Physicians' density (per 1000 population) & $1.1(1.1)$ & $1.6(1.4)$ & 0.1 to 1.0 \\
\hline Nurses' density (per 1000 population) & $2.8(3.8)$ & $3.9(3.6)$ & -0.1 to 2.3 \\
\hline Hospital beds (per 10000 population & $21.7(18.9)$ & $36.3(31.2)$ & 7.0 to 22.4 \\
\hline $\begin{array}{l}\text { Government expenditure on health per } \\
\text { capita (US\$) }\end{array}$ & $156(165)$ & $627(896)$ & 315 to 627 \\
\hline $\begin{array}{l}\text { General government expenditure on health } \\
\text { (\% of total government exp.) }\end{array}$ & $7.6(3.5)$ & $13.3(8.8)$ & -4.0 to 7.5 \\
\hline Total expenditure on health (\% of GDP) & $6.7(10.7)$ & $6.6(2.4)$ & -3.3 to 4.0 \\
\hline
\end{tabular}

a\% of women using contraception among those of reproductive age who are married or living with a partner; ${ }^{b} \%$ of 1 -year-olds immunized with 3 doses of DPT; c\% of 1-year-olds immunized with 1 dose of measles.

$C I=$ confidence interval; $S D=$ standard deviation; $H I V=$ human immunodeficiency virus; $D P T=$ diphtheria/pertussis/tetanus; $Y P L L=y e a r s$ of productive life lost; GDP = gross domestic product.

Annual per capita expenditure on health in MMC was one-fifth of that in nonMMC (US\$ 155.8 versus US\$ 627; 95\% CI: 315 to 626 ). Similarly, facilities such as hospital beds (36.3 versus 21.7 per 10000 population; $95 \%$ CI: 7.0 to 22.4) were better by a large margin in non-MMC (Table 3).

On correlation analysis, only the corruption perception index and income group were found to be significantly correlated at 0.78 , which was less than the cut-off.

\section{Associations between health indicators and outcomes}

Table 4 presents the unadjusted odds ratios (ORs) for associations between health indicators and outcomes. Almost all the variables were significantly associated in the univariate analysis with a few exceptions; for example, maternal mortality ratio, public expenditure on education and HIV prevalence were not significantly associated when analysed by the outcome male life expectancy. Similarly, gender equity index was not significantly associated with infant mortality rate.

The data were adjusted for countries' majority religion in the multivariable analysis. Corruption perception index were both important variables and were correlated so they were included in 2 separate models. In model 1 adult literacy rate, income group and improved water access were independent predictors of life expectancy for males $\left(R^{2}=54 \%\right)$, life expectancy for females $\left(R^{2}=69 \%\right)$ and infant mortality rate $\left(R^{2}=72 \%\right)$. Adult literacy rate and improved water access $\left(R^{2}=72 \%\right)$ were predictors of maternal mortality ratio. The only change identified in model 2 was the corruption perception index as a predictor of life expectancy for males $\left(R^{2}=52 \%\right)$, females $\left(R^{2}=67 \%\right)$, infant mortality rate $\left(R^{2}=\right.$ $72 \%)$ and maternal mortality ratio $\left(R^{2}\right.$ $=66 \%)($ Table 5).

\section{Discussion}

The study found that national health indicators in MMC were substantially worse than those in non-MMC. The differences were most prominent for the indicators of maternal and child health. Maternal mortality ratios and infant and under 5 years mortality rates were almost twice as high in MMC as in non-MMC. It is likely that the 3-year difference in overall life expectancy between MMC and non-MMC is largely mediated by excess early mortality. Nonetheless, adult mortality rates were higher in MMC than in non-MMC, although the magnitude of the difference was smaller. The substantial burden of communicable diseases, in spite of the lower prevalence of HIV, is indicative of the early stage of disease transition in MMC. However, being a MMC did not in itself account for these health disparities. The differences in health outcomes in our study were linked to differences in more predictable factors: overall GNI, literacy rates, access to clean water and level of corruption.

Low GNI was one of the key determinants of poor health indicators in MMC in our study. National economic status is an important determinant of health [26-28], although the relationship is not consistent across all countries. Improvements in health status in North America and Europe have been closely linked to economic growth [29]. However, there are examples of countries showing significant improvements in health status without major economic growth as well as of countries where an economic boom has had a negative impact on health outcomes [30]. Increasing national income leads to improvements in health only when coupled with advances in the status of 


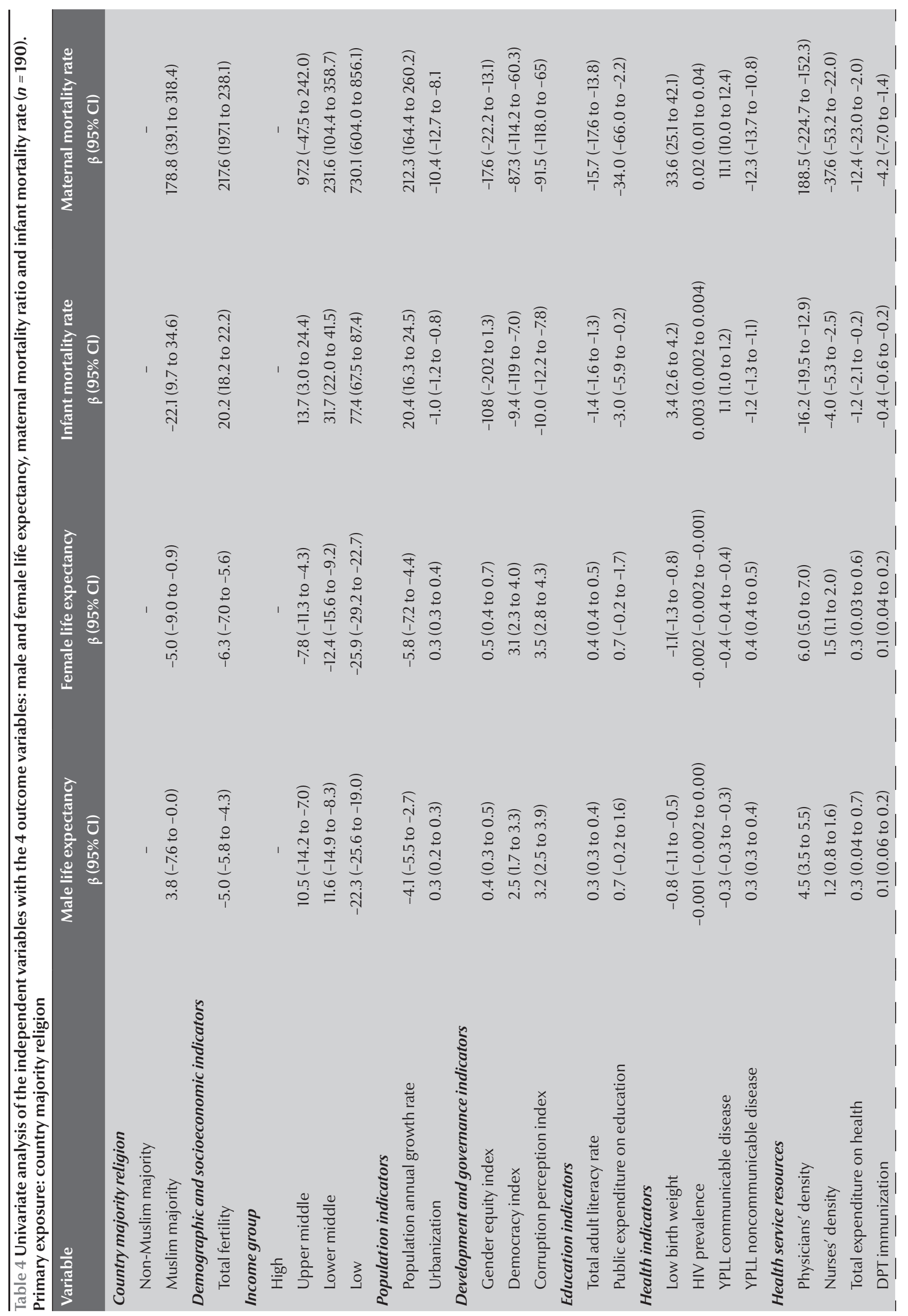


education [31] and empowerment, i.e. the ability of people, particularly poor people, to make independent decisions for their own well-being [32]. National wealth is not necessarily a barrier to or a guarantee of specific health outcomes, as evidenced by international comparisons. The United States ranks 4th in per capita GDP in the world (US\$ 45790 ); however, the life expectancy lags behind that of Jordan (GDP US\$ 4903) and Bosnia and Herzegovina (GDP US\$ 7468). More specifically, per capita spending on health also does not correlate well with health status. The level of a nation's wealth is linked very closely to what it spends on health. The larger the per capita income, the larger the expenditure is on health; with some notable exceptions, such as Pakistan. Health outcomes follow a nonlinear curve relative to per capita expenditure on health, asymptotically approaching a limiting level. However, in low income countries increasing health expenditures are associated with better health outcomes. For example Cuba spends relatively more and has higher life expectancies than would be expected for a country with a similar income [33]. Thus it is with concern that we note that in MMC per capita spending on health was only one-fifth of what it is in non-MMC.

The second determinant of poor health indicators in MMC in our study was the literacy rate. The association of literacy and health has been reported repeatedly in analyses of the post-Second World War decline of mortality in developing countries and of mortality differentials within their populations. Low literacy is associated with several adverse health outcomes [34]. Parental literacy in particular has an impact on the health of children [35]. There are mortality differences of up to 4 -fold between infants born to mothers with no education compared with those whose mothers have had secondary education [36].
The third independent factor associated with health differences in our study was the availability of clean water. One of the classic public health interventions, clean water is known to control the spread of communicable diseases [37]. Purification of water alone was thought to be responsible for half of all mortality reductions in some developed countries in the first half of the 20th century. An estimated $9 \%$ of the total burden of disease worldwide could be ameliorated by improved water quality and resource management and sanitation and hygiene [38].

The fourth factor which was a significant determinant of poor health indicators was the corruption perception index. Transparency International defines corruption as "the abuse of entrusted power for private gain" [39]. They estimated that the world spends more than 3 trillion dollars per year on health services. Such large flows of funds are an attractive target for abuse. According to the Global corruption report 2006, "the diversity of health systems worldwide, the multiplicity of parties involved, the paucity of good record keeping in many countries, and the complexity in distinguishing among corruption, inefficiency and honest mistakes make it difficult to determine the overall costs of corruption." Up to now there has been little evidence published in the medical literature about the link between corruption and health outcomes and our study provides useful evidence of a link.

The gradient in health within countries and the marked health inequities between countries can be linked to the unequal distribution of power, income, goods or services, and the consequent disparities in the circumstances of people's lives. Together, the structural determinants and conditions of daily life constitute the social determinants of health and are responsible for a major part of the health inequities between 


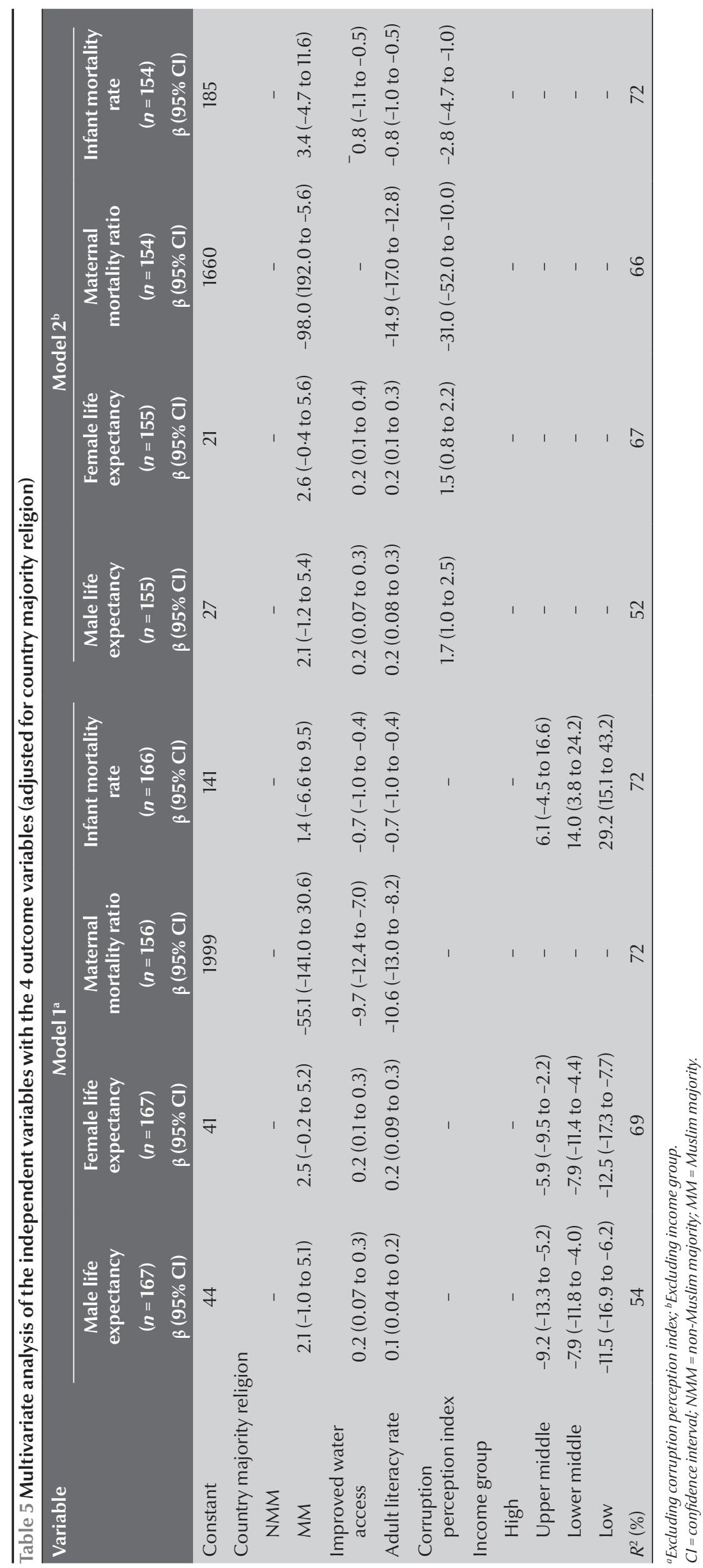

and within countries [3]. The premise of this study was to define religion as one of many axes of social stratification, even though there are marked social, demographic, economic and political differences within and between these countries. Although we saw major differences in health outcomes between MMC and non-MMC, this study does not prove causality, i.e. that the majority religion of the countries was responsible for this difference. The study showed that the differences between $\mathrm{MMC}$ and non-MMC were due to differences in determinants such as education, wealth and infrastructure. The underlying determinants in themselves also cannot be causally connected to poor health outcomes. Like religion, these determinants are possibly part of a complex causal pathway. Recently the health ministers of countries of the Organisation of the Islamic Conference called for "solidarity in action in dealing with eradication of poverty and public health issues particularly diseases and epidemics" [40]. Based on our findings, we believe that the focus needs to be expanded to include encouraging literacy, provision of clean water and improving the governance structure.

\section{Limitations}

There are some methodological limitations to the study. First, ecological analyses cannot measure correlates of risk at the individual level and the temporal sequence of events is unknown. Secondly, the study was based on secondary data and the quality of such aggregate data is likely to vary depending on the public health and information infrastructure of a given country. Thirdly, it is possible that some confounders were not considered in the study due to the unavailability of data-health service quality, for example-despite every attempt to incorporate all available potential variables. It would have been useful to study the time trends within MMC and non-MMC, but such an analysis 
was not possible due to the unavailability of historical data for all countries. Despite these limitations of data and of definitions, we believe the differences observed between the MMC and non$\mathrm{MMC}$ were unlikely to be due to chance alone.

\section{Conclusion}

In conclusion, the study shows that countries with majority Muslim populations are at a significant disadvantage in terms of health. The factors that explain these differences include low economic development, low levels of literacy, poor availability of clean water and the level of corruption. Substantial future research should focus on the "determinants of the determinants" in the context of Muslim countries.

\section{References}

1. World health report 2000. Health systems: improving performance. Geneva, World Health Organization, 2000.

2. Feachem RG. Poverty and inequity: a proper focus for the new century. Bulletin of the World Health Organization, 2000, 78:1-2.

3. Commission on Social Determinants of Health. Closing the gap in a generation: health equity through action on the social determinants of health. Geneva, World Health Organization, 2008.

4. Willets RC et al. Longevity in the 21st century. London, Institute of Actuaries and Faculty of Actuaries, 2004.

5. Laird LD et al. Muslim patients and health disparities in the UK and the US. Archives of Disease in Childhood, 2007, 92:922926.

6. Talukdar A et al. Risk of HIV infection but not other sexually transmitted diseases is lower among homeless Muslim men in Kolkata. AIDS (London, England), 2007, 21:2231-2235.

7. Szczepura A, Price C, Gumber A. Breast and bowel cancer screening uptake patterns over 15 years for UK south Asian ethnic minority populations, corrected for differences in socio-demographic characteristics. BMC Public Health, 2008, 8:346.

8. List of countries by Muslim population. Wikipedia [website] (http://en.wikipedia.org/wiki/Islam_by_country, accessed 22 May 2011).

9. Human development in the Muslim world. (Doha discussion papers). Washington DC, US-Islamic Development Forum, The Brooking Institution, 2008.

10. List of Muslim-majority countries. Wikipedia [website] (http:// en.wikipedia.org/wiki/List_of_Muslim-majority_countries, accessed 29 July 2011).

11. How we classify countries. World Bank [online factsheet] (www.worldbank.org/data/countryclass/classgroups.htm, accessed 22 May 2011).

12. Core health indicators. WHO Statistical Information Systems (WHOSIS). World Health Organization [online] (http://www. who.int/whosis/database/core/core_select.cfm, accessed 22 May 2011).

13. Statistics and databases. Statistical Economic and Social Research and Training Center from Islamic Countries [website] (http://www.sesric.org/oic-member-countries.php, accessed 22 May 2011).

14. Quick query. The World databank [website] (http://databank. worldbank.org/ddp/home.do, accessed 29 July 2011).

15. International Human Development Indicators. United Nations Development Programme [website] (http://hdr.undp.org/en/ statistics/, accessed 22 May 2011).

16. Statistical databases. United Nations Statistics Division [online database] (http://unstats.un.org/unsd/databases.htm, accessed 22 May 2011).

17. Information by country and programme. United Nations International Children Education Fund [online database] (http:// www.unicef.org/infobycountry/index.html, accessed 22 May 2011).

18. Maternal mortality in 2000: estimates developed by WHO, UNICEF and UNFPA [online document] (http://reliefweb. int/sites/reliefweb.int/files/resources/5CEB91DA5C1C385 049256DC800067E6F-who-saf-22oct.pdf, accessed 29 July 2011).

19. UNESCO Institute for Statistics. United Nations Educational, Scientific and Cultural Organization [online database] (http:// stats.uis.unesco.org/unesco/TableViewer/document. aspx?Reportld=143\&IF_Language=eng, http://www.unicef. org/infobycountry/index.html, accessed 22 May 2011).

20. The World Fact Book. Central Intelligence Agency [online database]. (https://www.cia.gov/library/publications/the-worldfactbook/index.html, accessed 22 May 2011).

21. Google Scholar [search engine] (http://scholar.google.com. $\mathrm{pk} / \mathrm{schhp}$ ?hl=en\&tab=ws, accessed 22 May 2011).

22. WHO Statistical Information Systems (WHOSIS). World Health Organization [online database] (http://www.who.int/whosis/ indicators/compendium/2008/en/index.html, accessed 22 May 2011).

23. Reidpath DD, Allotey P. Infant mortality rate as an indicator of population health. Journal of Epidemiology and Community Health, 2003, 57:344-6.

24. Health indicators: building blocks for health situation analysis. Epidemiological Bulletin, 2001, 22:1-5. >

25. Murthi M, Guio AC, Dreze J. Mortality, fertility, and gender bias in India: A district-level analysis. Population and Development Review, 1995, 21(4):745-782.

26. Pritchett L, Lawrence H. Summers. Wealthier is Healthier. Journal of Human Resources, 1996, 31:841-68.

27. Dollar D. Is globalization good for your health? Bulletin of the World Health Organization, 2001, 79:827-33.

28. Preston SH. Causes and consequences of mortality declines in less developed countries during the twentieth century. In: Easterlin RA, ed. Population and economic change in developing countries. Chicago, University of Chicago Press, 1980:289-360.

29. Cutler DM, Lleras-Muney A. The determinants of mortality. Cambridge, Massachusetts, National Bureau of Economic Research, 2006 (NBER Working Paper series No. 11963).

30. Drèze J. India: development and participation. Oxford, Oxford University Press, 2002.

31. Human development report 2005. New York, United Nations Development Programme, 2005.

32. Stern NH, Dethier JJ, Rogers FH. Growth and empowerment: making development happen. Cambridge, Massachusetts, MIT Press, 2005.

33. Skolnik RL. Health education, poverty and economy. In: Riegelman R, ed. Essentials of global health. Sandbury, Jones and Bartlett Learning, 2008:41-55. 
34. Dewalt DA et al. Literacy and health outcomes: a systematic review of the literature. Journal of General Internal Medicine, 2004, 19:1228-39.

35. Kiros GE, Hogan DP. War, famine and excess child mortality in Africa: the role of parental education. International Journal of Epidemiology, 2001, 30:447-55.

36. World development report 2006. Equity and development. New York, World Bank/ Oxford University Press, 2006.

37. Ezzati $M$ et al. Selected major risk factors and global and regional burden of disease. Lancet, 2002, 360:1347-1360.
38. Prüss-Üstün ABR, Gore F, Bartram J. Safer water, better health: costs, benefits and sustainability of interventions to protect and promote health. Geneva, World Health Organization, 2008.

39. What is Transparency International? Transparency International: the global coalition against corruption [website] (http://www. transparency.org/about_us, accessed 29 July 2011).

40. Kuala Lumpur Declaration 2007. First Islamic Conference of Health Ministers, 12-15 June 2007, Kuala Lumpur, Malaysia (http://www.sesric.org/imgs/news/File/KL.pdf, accessed 29 July 2011).

\section{World Conference on Social Determinants of Health}

To build support for the implementation of action on social determinants of health, the World Health Organization (WHO) is convening the World Conference on Social Determinants of Health on 19-21 October, 2011, in Rio de Janeiro, Brazil. The conference is organized in accordance with the World Health Assembly Resolution WHA62.14 (2009) and will be hosted by the Government of Brazil. The Brazilian Ministry of Health, the Oswaldo Cruz Foundation (Fiocruz) and the Brazilian Ministry of Foreign Affairs are working closely with WHO on preparing the event.

The conference will bring together Member States and stakeholders to share experiences on policies and strategies aiming to reduce health inequities. The event will provide a global platform for dialogue on how the recommendations of the WHO Commission on Social Determinants of Health (2008) could be taken forward. The key aim of the process is to draw lessons learnt and to catalyse coordinated global action in five key areas.

- governance to tackle the root causes of health inequities: implementing action on social determinants of health;

- the role of the health sector, including public health programmes, in reducing health inequities;

- promoting participation: community leadership for action on social determinants;

- global action on social determinants: aligning priorities and stakeholders;

- monitoring progress: measurement and analysis to inform policies on social determinants.

The conference will be attended by ministers of health, foreign affairs, the environment and other sectors; representatives of international agencies, philanthropic institutions and civil society organizations; leading academics and technical experts; and representatives from the private sector. The conference's outcome document, the Rio Declaration, will help to build high-level international backing for the further development and implementation of national policies to address social determinants of health. Further information about the conference can be found at: http://www.who.int/sdhconference/en/ 